\title{
School Curriculum Focused on Class Interaction According to Experimental and Control Group of Teachers' Perceptions
}

\author{
Refik Çela, PhD Student \\ Programme Implementation Manager, Save the Children, Tirana, Albania \\ Email: refikcela@yahoo.com
}

\section{Doi:10.5901/jesr.2014.v4n6p407}

\section{Abstract}

Based on data by experimental and control group of teachers it has been resulted that in general school curriculum complete pupils's interests. Meantime there are conceptual overloads problems, non accordance of colour with pupils' group ages, that do not create the possibilities to use in different contexts by the pupils. This is a positive conclusion meaning the flexibility of curriculum, but it does not give us the data if this flexibility would have the indication on interaction in class that would influence pupils' achievements.

\section{Introduction}

This dilemma of the relationships between of teacher- pupil and pupil- pupil interaction' level and pupils' achievements that is directly linked to class climate is the premise of this paper.

The aim is to find out the role of school curriculum in relationships between teacher- pupil and pupil- pupil interaction and pupils' academic and social achievements, related to other variables as well.

The paper focus on teachers' perceptions on school curriculum as a variable that influences in relationships between teacher- pupil and pupil- pupil interaction and pupils' academic and social achievements.

\section{Methodology of Research}

The main instrument of research, was structured questionnaire that was made by five dimensions: (1) class climate, (2) teacher- pupil and pupil- pupil interaction in class and pupils' social achievements, (3) teacher- pupil and pupil- pupil interaction in class with pupil's academic achievements, (4) teacher professional development, (5) curriculum.

Besides statistical analysis made to verify the relationships between variables, school curriculum' frequencies values according to pupils and teachers' perceptions are compounded the basis of findings and conclusions of paper.

Teachers' sample has been selected form teachers that teach pupils of, fourth, fifth, sixth grades of schools supported by Save the Children Albania Organization in six counties in the country. Teachers's sample was compounded by experimental and control group. The data came out by two groups has been compared and analyzed.

\section{Findings}

Curriculum according to Taba is everything taught in school, that means: (1) written curriculum compounded by curriculum framework, learning and achievements' standards, subjects' programs, as well as other components support its using, and (2) used curriculum that means teaching process in classroom under teachers' guide as well as with pupils' cooperation. The findings of this paper has been generated by a structured questionnaire with teachers of experimental and control group that teach at fourth, fifth, sixth grades of primary school in six counties of the country.

\subsection{Curriculum- experimental group}

How much curriculum, that is to say school programs and texts allow pupils to apply their knowledge in different contexts. These are the values of this variable generated by teachers' sample- experimental group. 
Table 1: Distribution of curriculum variable values - experimental group

\begin{tabular}{|c|l|c|c|}
\hline No & Curriculum & Frequencies & $\%$ \\
\hline 1 & Never & 1 & 0.70 \\
\hline 2 & Sometimes & 28 & 19.20 \\
\hline 3 & Frequently & 92 & 63.00 \\
\hline 4 & Always & 25 & 17.10 \\
\hline
\end{tabular}

Almost $80 \%$ of respondents teachers' experimental group, report that there is flexible curriculum frequently or always. Meanwhile about $20 \%$ of them report that there is flexible curriculum never or sometimes. This means that majority of teachers' experimental group report that generally curriculum: programs and texts are in accordance with pupils' interests, meanwhile $1 / 4$ of them report that curriculum do not create conditions that pupils apply their knowledge in different contexts.

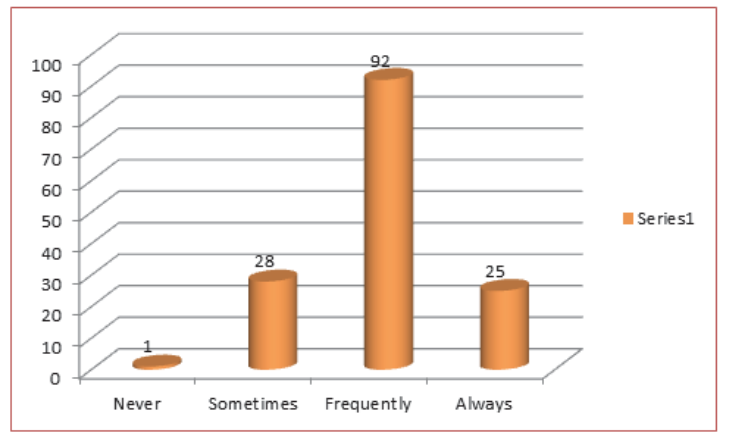

Chart 1: Distribution of curriculum variable values - experimental group in \%

Statistical constants values of curriculum variable according to teachers' experimental group: mean 2.9658 , median 4 , standard deviation 0.62604 , as well as minimum 1 , and maximum 3 , confirm tendency in distribution of values frequencies of curriculum variable according to teachers' experimental group.

\subsection{Curriculum- control group}

These are the values of this variable generated by teachers' sample- control group.

Table 2: Distribution of curriculum variable values - control group

\begin{tabular}{|c|l|c|c|}
\hline No & Curriculum & Frequencies & $\%$ \\
\hline 1 & Never & 0 & 0.00 \\
\hline 2 & Sometimes & 10 & 20.40 \\
\hline 3 & Frequently & 33 & 67.30 \\
\hline 4 & Always & 6 & 12.20 \\
\hline
\end{tabular}

Almost $80 \%$ of respondents teachers' control group, report that there is flexible curriculum frequently or always. Meanwhile about $20 \%$ of them report that there is flexible curriculum never or sometimes. This means that majority of teachers' control group in an absolutely equal way with experimental group think that generally curriculum: programs and texts are in accordance with pupils' interests, meanwhile $1 / 4$ of them think that curriculum does not create conditions that pupils apply their knowledge in different contexts. 


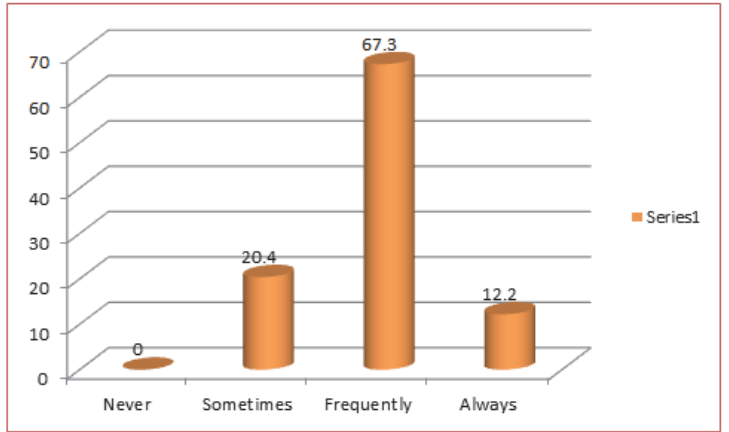

Chart 2: Distribution of curriculum variable values - control group in \%

Statistical constants values of curriculum variable according to teachers' control group: mean 2.9658, median 3, standard deviation 0.62604 , as well as minimum 2, and maximum 4, confirm tendency in distribution of values frequencies of curriculum variable according to teachers' control group.

Regarding to curriculum variable values, if it is flexible in the meaning that gives space to apply knowledge in different contexts by the pupils, two groups experimental and control one have reported the same figure; $80 \%$ of respondents' teachers from experimental group and $80 \%$ of respondents teachers' from control group reports that curriculum is flexible frequently or always in their classes; meanwhile $20 \%$ of respondents teachers from experimental group and $20 \%$ of respondents teachers from control group reports that curriculum is flexible never or sometimes in their classes.

\section{Conclusions}

- Curriculum meaning programmes and school texts that are in the usage of pupils and teachers complete pupils' s interests in general.

- Meantime there are conceptual overloads problems, non accordance of colour with pupils' group ages, that confirm also from the qualitative data, that do not create the possibilities to use in different contexts by the pupils.

- $1 / 4$ of teachers think that curriculum does not create the facilities for the pupils to apply the knowledge in different contexts.

- This is a positive conclusion meaning the flexibility of curriculum, but it does not give us the data if this flexibility would have or not the indication on interaction in class that would influence pupils' achievements.

\section{Recommendations}

- Teachers should create in their teaching a cooperation, collaboration, and inclusive climate in restructuring of knowledge, and abilities that would influence on promotion of teaching with the pupil in the center.

- Teachers should create in their teaching a cooperation, collaboration, and inclusive climate of pupils in class that would increase pupil's participation in the learning process and would also support their achievements.

- Teachers as well as educational institutions should revise and adapt curriculum to avoid conceptual overloads problems, non accordance of colour with pupils' group ages in order to create the possibilities to use in different contexts by the pupils.

\section{References}

Alig-Mielcarek, A. J. J, Hoy, W. K. (2005). Instructional leadership: Its nature, meaning,and influence. Pearson Education, Inc. Boston, Sh. B. A.

Bottoms, G \& O, Neill, K. (2001). Learning to teach. Handbook of educational psycology. New York: Macmillan.

Cross, K. P. (2001). Motivation: Er...Will that be on the test? The Cross papers Number 5. League for Innovation in the Community 
College.

Di Paola, F. M., Hoy, K. W. (2008). Principal Improving Instruction. Pearson Education, Sh. B. A.

Eschenmann, K. (1991). Student Perceptions of Teaching Style in The Health Occupation Classroom. Journal of Health Occupations Education, 6(1).

Fullan, M. G. (1991). The new meaning of educational change. New York: Teachers college press.

Gardner, H. (2003). Dimensionet e Mendjes. Insituti i Studimeve Pedagogjike. Tiranë.

Gerald C.Ubben, Larry W. Hughes, Cynthia J. Norries (2007). The principal- Creative leadership for excellence in schools. Pearson Education, Sh. B. A.

Hoy, A. W., \& Hoy, W. K. (2006). Instructional leadership: A learning- centered guide. Boston: Allyn and Bacon. Inc. Review, Spring 2008.

International program for primary education(1998). Step by step. [Versioni i librarisë dixhitale]. Marrë nga: http://www.stepbystep.org. mk/finalni_ang/fondacija/fond\%201a.htm

Karaj,Th. (2010) . Raport sondazhi për ndërveprimin mësues- nxënës. [Broshurë]. Tiranë.

King D. (2002). The changing shape of leadership. Educational leadership.

Lavoie, R. (2007). The Motivation Breakthrough: 6 secrets to turning on the tuned-out child. New York: Simon \& Schuster.

Leithwood, K. \& Jantzi, D. (1999). Transformational School Leadership Effects: A Replication. School Effectiveness and School Improvement. Vol.10, No.4, f.453.

Marzano, R. J., \& Marzano, J. S. (2008). Dimensions of Learning. Michigan Department of Education. Tending to the Spirit/Culture. Retrieved January 11, 2009.

Mita, N. etj . (1999). Metoda të mësimdhënies. Tiranë.

Murphy, J. (1990). Principal instructional leadership. Advances in Educational Administration. Pearson Education, Sh. B. A.

Musai, B (2003). Metodologji e mësimdhënies. Tiranë.

Musai, B. (2009). Të shkruajmë objektiva mësimorë për mësimdhënien dhe vlerësimin. Tiranë.

Orstein, C. A., Hunkins P. F. (2003). Kurrikula - bazat, parimet dhe problemet. Instituti i Studimeve Pedagogjike. Tiranë.

Patterson, J. (1993). Leadership for tomorrow's school. Alexandria,VA: Association of supervision and curriculum development.

Payne, R. K., PhD. (2003). A Framework for understanding Poverty. Highlands, Texas: Aha! Process Inc., (Original work published 1996).

Picciano, A. G. (2006). Educational leadership and planning for technology. $4^{\text {th }}$ Edition. Pearson Prentice Hall.

Pollard, A. , Tann, S. (1999). The reflective teaching in the primary education. . [Versioni i librarisë dixhitale]. Marrë nga: http://reflectivepractice-cpd.wikispaces.com/Reading

Project in Albania (1998). HRE in pegadogical universities. [Broshurë]. Tiranë. (QTKA) Qendra Kombëtare e Trajnimit dhe Kualifikimit (2005). Mësimdhënia me në Qendër Nxënësin. Tiranë.

Robertson, P. J. dhe Kerri L. B. (1998). Improving Schools Through School-Based Management: An Examination of the Process of Change. School Effectiveness and School Improvement. Vol.9, No.1, f.29.

RWCT Project (1999). Critical thinking across reading and writing. [Versioni i librarisë dixhitale]. Marrë nga: http://www.criticalthinking international.org/programs?id=13

Senge, P., Nelda Cambron- McCabe, N., Luca, T., Smith, Dutton, J. B., Kleiner, A. (1999) Shkollat e të Nxënit. Instituti i Studimeve Pedagogjike. Tiranë.

Stewart, E. B (2008). Individual and School Structural Effects on African American High School Students' Academic Achievement. The High School Journal 91.2 (2007) 16-34.

Tamo, A., Karaj, Th. (2010). Zhvillimi i shkathtësive të të menduarit kritik dhe i bashkëpunimit në fillimet e adoleshencës. [Broshurë]. Tiranë.

UNICEF-Serbia \& Montenegro (1998). Active learning, Teacher manual [Versioni i librarisë dixhitale]. Marrë nga: http://www.unicef.org/serbia/active_learning_2.pdf

Van de Grift. W. and Houtveen A.A.M. (1999). Educational leadership and pupil achievement in primary education. Department of Educational Sciences, Utrecht University. School

Veenman, S e të tjerë.(1998). Implementation Effects of a Program for the Trianing of Coaching Skills with School Principals. School Effectiveness and School Improvement. Vol.9, No.2, f.137.

Vollansky, A. and Bar-Elli, D.(1996). In Israel / Moving Toward Equitable School-Based Management. Site-Based Management: Making It Work. Volume 53, No 4. f.60-62.

Vroom, V. H. (1995). Work and Motivation.p.75-89. San Francisco: Jossey-Bass Inc., (Original work published 1964).

Weber, J. (1996). Leading the instructional program. In S. Smith \& P. Piele, School leadership.Eugene Clearing House of Management.

Wiseman, D. G., PhD, \& Hunt, G. H., PhD. (2001). Best Practice in Motivation and management in the classroom. Springfield, Illinois. Charles C. Thomas Publisher Ltd.

Yin Cheong Cheng. (1996). School effectiveness and school-based management. A mechanism for development. Falmer Press. 